\title{
PENDAMPINGAN BELAJAR DARING UNTUK MENGURANGI KECANDUAN GADGET PADA SISWA SEKOLAH DASAR
}

\section{Alfath Iqbaal Chairulhaq ${ }^{1}$, Alvina Mutia Hendarti ${ }^{2}$, Reza Milenia Fendi ${ }^{3}$, Achmad Room Fitrianto ${ }^{4}$}

Universitas Islam Negeri Sunan Ampel Surabaya

* Corresponding Author. E-mail: ${ }^{1}$ alfath.iqbaal.c@gmail.com

\begin{abstract}
Abstrak
Negara-negara di dunia sedang dilanda wabah penyakit yang disebabkan virus COVID-19. Dengan adanya wabah ini pemerintah memberi kebijakan agar aktivitas masyarakat dilakukan dari rumah untuk mengurangi persebaran penyakit. Salah satunya dalam bidang pendidikan, yang sebelumnya dilakukan dengan secara tatap muka kini dilakukan dengan pembelajaran jarak jauh. Hal tersebut menimbulkan permasalahan baru yakni ketergantungan penggunaan gadget pada anak. Oleh karena itu perlu pengawasan orang tua terhadap penggunaan gadget pada anak. Peneliti dalam proses pendampingan ini bertujuan untuk meningkatkan motivasi dan semangat belajar pada anak - anak dengan menggunakan metode pembelajaran yang menyenangkan agar lebih produktif selama pembelajaran jarak jauh. Penelitian ini menggunakan metode pendekatan PAR (participatory action research), yaitu menekankan pada partisipasi dan kolaborasi untuk mengidentifikasi masalah penelitian berdasarkan kebutuhan dari subjek yang diteliti. Hasil pendampingan belajar menunjukkan bahwa para pelajar sangat antusias dalam proses pendampingan belajar berlangsung, pelajar lebih senang pembelajaran secara tatap muka dibandingkan pembelajaran daring, tugas sekolah para belajar dapat dikerjakan dengan baik, dan dapat memanfaatkan fasilitas umum lebih produktif.
\end{abstract}

Kata Kunci: Pendampingan Belajar, Motivasi Belajar, Efektivitas Pembelajaran Jarak Jauh

\section{OPTIMIZING ONLINE LEARNING ASSISTANCE TO REDUCE GADGET ADDICTION IN ELEMENTARY SCHOOL STUDENTS}

\footnotetext{
Abstract

Countries around the world are experiencing outbreaks of disease caused by the COVID-19 virus. With this outbreak, the government has given a policy so that people's activities are carried out from home to reduce the spread of the disease. One of them is in the field of education, which was previously done face-to-face, now it is done by distance learning. This raises a new problem, namely dependence on the use of gadgets in children. Therefore, it is necessary for parents to supervise the use of gadgets in children. Researchers in this mentoring process aim to increase motivation and enthusiasm for learning in children by using fun learning methods to be more productive during distance learning. This study uses a PAR (participatory action research) approach, which emphasizes participation and collaboration to identify research problems based on the needs of the subject being studied. The results of learning mentoring show that students are very enthusiastic in the ongoing learning mentoring
} 
process, students prefer face-to-face learning compared to online learning, students' school work can be done well, and can use public facilities more productively.

Keywords: Learning Assistance, Learning Motivation, Distance Learning Effectiveness

\section{Pendahuluan}

Negara - negara di dunia sedang dilanda wabah penyakit virus COVID-19 atau dikenal dengan corona. Di Indonesia Per 24 Agustus 2021 total jumlah pasien covid sebanyak lebih dari 4 juta yakni 4.008.166 dengan kasus kematian sebanyak 128.252(World Health Organization, 2021). Tingginya kasus dan angka kematian,tentu membuat setiap orang harus senantiasa waspada akan marabahaya yang mengintai. Hal ini menimbulkan berbagai perubahan dampak perilaku utamanya Virus ini menyebabkan berbagai dampak dalam kehidupan seperti perekonomian maupun pendidikan (Fitrianto, 2021, p. 56; Suprihatin et al., 2020). Sampai saat ini dengan adanya virus ini pemerintah memberi kebijakan agar aktivitas masyarakat dilakukan dari rumah untuk mengurangi persebaran virus corona.Kota Mojokerto menerapkanberbagai kebijakan yang selaras dengan Pemerintah Pusat untuk menekan laju kasus COVID-19, Mulai dari Pembatasan Sosial yang Berskala Besar (PSBB) sampai Pemberlakuan Pembatasan Kegiatan Masyarakat (PPKM) seperti yang baru baru ini. Dalam masa pandemi seperti ini, dalam dunia pendidikan menjadi tantangan tersendiri bagi seorang pengajar dan pelajar. Pola pendidikan menjadi berubah, dimana yang biasanya pembelajaran dilaksanakan secara tatap muka langsung, saat ini digantikan oleh pembelajaran daring atau jarak jauh. Para tenaga pengajar tentunya harus beradaptasi dengan kondisi ini, begitu pula bagi para pelajar. Namun tak terasa juga pembelajaran jarak jauh pun ini sudah terlewati selama satu tahun lebih, guna untuk mengurangi resiko penularan COVID-19 dalam lingkungan pendidikan. Tidak semua pelajar dapat melakukan pembelajaran daring secara maksimal salah satu faktornya hambatan minimnya akses internet di beberapa daerah terpencil. Namun, bagi daerah yang memiliki akses internet yang baik, itu bukanlah suatu hambatan dan masalah bagi mereka.

Kendati bukan menjadi suatu hambatan,hal ini justru menimbulkan permasalahan baru yakni perubahan penggunaan gadget yang cenderung malah menimbulkan ketagihan.Di Kota Mojokerto perasaan dari para siswa dalam melaksanan pembelajaran secara daring memiliki perbedaan dengan pada saat mereka dapat melakukan kegiatan belajar secara tatap muka di sekolah. Selain itu banyak siswa menganggap bahwasekolah adalah kegiatan yang sangat menyenangkan, mereka bisa berinteraksi satu sama lain. Sekolah dapat meningkatkan keterampilan sosial dan kesadaran kelas sosial siswa(Syah, 2020, p. 396). Kendati demikian dalam kegiatan pembelajaran yang dimana membutuhkan kesabaran ekstra dalam pengawasan dan pendampingan yang dilakukan agar pembelajaran daring yang merupakan proses pembelajaran yang dilakukan dalam jarak jauh melalui media berupa internet dan alat penunjang lainnya seperti telepon seluler dan komputer dapat terlaksana secara maksimal. Pembelajaran daring ini memberikan keluasaan waktu belajar, dimana proses belajar dapat dilakukan kapanpun dan dimanapun. Interaksi Siswa dengan guru dilakukan melalui berbagai macam media komunikasi berbasis platform seperti google classroom, WhatsApp Chat, dan aplikasi yang sejenis. Prawanti dan Sumarni(2020, p. 287) menuturkan Pandemic COVID-19 menimbulkan dampak jangka pendek pada keberlangsungan pembelajaran dan dampak ini akan dirasakan oleh seluruh orang yang berkaitan dengan bidang pendidikan entah itu di desa maupun di kota.Selain itu, orang tua untuk dituntut selalu mendampingi anaknya selama belajar dari rumah dalam metode pembelajaran daring .Dalam pembelajaran daring peran orang tua siswa sangat penting karena orang 
tua yang harus membimbing dan mengawasi anak-anak saat belajar di rumah.Namun, tidak kurang orang tua yang merasa bahwa mereka kesulitan saat mendampingi anaknya dalam masa pembelajaran daring tersebut.Penyebab hal ini adalah banyak orang tua yang tidak menguasai cara penggunaan teknologi informasi secara efektif yang merupakan media inti dalam pembelajaran daring.

Melihat dari deskripsi latar belakang diatas. Maka tujuan dilakukannya program kerja ini yaitu untuk membantu pendampingan terhadap anak sekolah yang memerlukan pengarahan maupun pengawasan dalam pembelajaran daring ini, terutama dalam membantu memahami persoalan dari mata pelajaran yang sulit selama pembelajaran daring dari sekolah. Hal ini merupakan upaya untuk mewujudkan salah satu Tri Dharma Perguruan Tinggi yakni pengabdian masyarakat, melalui program ini mahasiswa diharapkan dapat memberikan kontribusinya dalam bidang pendidikan demi menambah memajukan pengetahuan mengenai dunia pendidikan.Selain itu program ini berdampak positif dimana dapat memberikan ilmu maupun pengalaman yang baru untuk para mahasiswa dengan bentuk kepeduliannya terhadap masyarakat. Tujuan dari penulisan ialah untuk mengukur tingkat efektivitas yang mampu diperoleh dalam pendampingan yang dilakukan terhadap keberhasilan dan perubahan pola perilaku dari anak sekolah dasar yang menjadi sasaran program dijalankan.

\section{METODE}

Peneliti menggunakan jenis penelitian PAR (Participatory Action Research). PAR adalah sekumpulan metode penelitian yang menekankan pada partisipasi dan kolaborasi dari berbagai pihak dalam mengelola suatu penelitian. (Syanas et al., 2019). PAR merupakan salah satu penelitian yang mencari sesuatu untuk melakukan proses perubahan sosial. Perubahan sosial yang dimaksud ialah bagaimana proses pemberdayaan dapat diwujudkan melalui pencapaian tujuan yang diinginkan oleh masyarakat tersebut (Rahmat \& Mirnawati, 2020). Menurut Yoland Wadworth, Participatory Action Research (PAR) adalah istilah yang memuat seperangkat asumsi yang mendasari paradigma baru ilmu pengetahuan dan bertentangan dengan paradigma pengetahuan tradisional(Afandi, 2013).Peneliti melakukan penelitian secara partisipasi dan kolaborasi. Penelitian melakukan penelitian partisipasi dengan melakukan pendampingan terhadap anak anak SD dan melakukan kolaborasi dengan TPQ Nurul Qur'an yang berada di Griya Permata Meri Mojokerto.

Berdasarkan metode PAR, ketiga variabel diuraikan sebagai berikut, Participatory atau partisipasi, pada tahap partisipasi ini dengan melibatkan komponen masyarakat dalam melakukan identifikasi masalah. Partisipasi kami melibatkan anak anak SD kelas 5 dan 6 di perumahan GPM Mojokerto untuk mencari solusi dan bekerja secara bersama - sama. Action atau aksi, setelah mengetahui masalah yang dialami secara mendalam barulah memasuki tahap kedua yakni mencari alternative untuk memecahkan masalah tersebut kemudian direalisasikan ke dalam program kerja yang sudah ditentukan. Research atau penelitian, pada tahap ini merupakan tahap penelitian tentang permasalahan yang terjadi di masyarakat terutama anak - anak dan permasalahan tersebut diteliti secara mendalam sehingga mengetahui penyebab dan akibatnya secara jelas dan detail.

Tahap dari pelaksaan penelitian adalah 1) Observasi, 2) Perencanaan kegiatan, 3) Pembuatan jadwal kegiatan, 4) Pelaksanaan, 5) Evaluasi, urutan tersebut dapat dilihat dalam Diagram Alir 1 


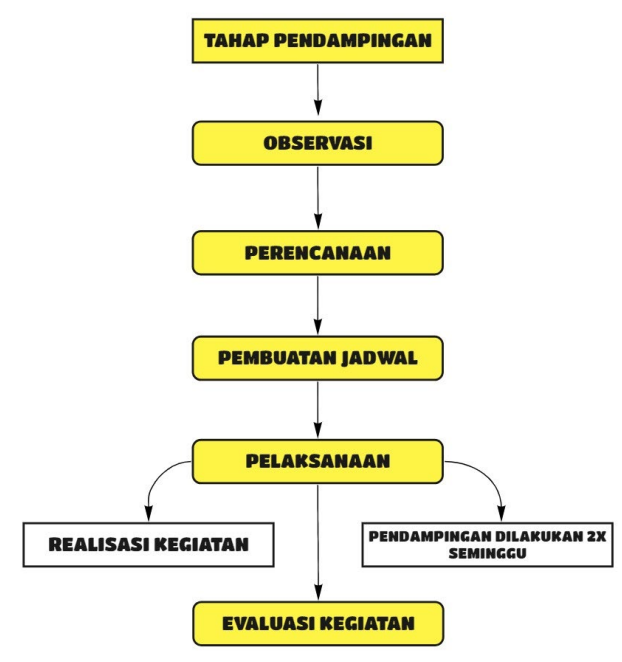

Diagram Alir 1 Tahapan Penelitian

Tahap observasi dilakukan dalam rangka untuk mengetahui dan mengidentifikasi masalah pembelajaran daring yang dialami anak - anak sekolah dasar di perumahan Griya Permata Meri. Tahap perencanaan dilakukan dengan menentukan sasaran dan melakukan koordinasi dengan Ketua RT setempat untuk mengadakan pendampingan belajar. Tahap pembuatan jadwal dilakukan dengan anak anak dengan membuat kelompok belajar oleh 8 anak dan belajar dilakukan 2 kali perminggu yakni di hari Senin dan Rabu yang dilakukan selama 3 minggu. Tahap pelaksanaan adalah realisasi kegiatan pendampingan belajar yang dilakukan oleh mahasiswa Kelompok Kerja Nyata (KKN) yang dilakukan oleh 3 orang mahasiswa sebagai pendamping di bawah bimbingan Dosen Pembimbing Lapangan.

\section{HASIL DAN PEMBAHASAN}

Masuknya virus corona di Indonesia mengakibatkan hampir semua kegiatan dilaksanakan secara online, salah satunya dalam kegiatan belajar mengajar yang tadinya dilakukan di sekolah, namun saat ini menjadi belajar dari rumah secara daring (Sumarno, 2020). Dalam era kemajuan teknologi saat ini, penggunaan telepon pintar (smartphone) bukan menjadi hambatan bagi generasi milenial apalagi dalam masyarakat perkotaan. Dengan banyaknya berbagai media pembelajaran dalam menunjang kegiatan pembelajaran jarak jauh seperti, aplikasi google classroom, google meet, zoom, dan lain- lain. Aplikasi tersebut telah menjadi keseharian para pelajar sebagai media pembelajaran jarah jauh di masa pandemi. Dan digunakan untuk meningkatkan efisien dan efektivitas dalam pembelajaran jarak jauh(Nuriansyah et al., 2020).

Problematika dalam pembelajaran jarak jauh sering dialami oleh siswa. Tidak semua siswa memliki sarana dan prasarana yang memadai. Misal anak yang tidak memiliki telepon pintar (smartphone) sendiri dan gagap teknologi yang dimana para penggunanya dapat mengoperasikannya sehingga membuat para pelajar terhambat dalam memahami materi yang ada. Sedangkan penggunaan telepon pintar (smartphone) jika digunakan secara optimal dapat berpengaruh signifikan dalam meningkatkan hasil belajar siswa(Rosiyanti \& Muthmainnah, 2018). Masyarakat khususnya bagi yang kurang mampu, menjadi hambatan bagi mereka terhadap sarana dan prasarana untuk anak-anak mereka. Apalagi di daerah pelosok yang sulit terjangkau jaringan internet sehingga menyulitkan para pelajar menghadapi pembelajaran daring(Yuhenita et al., 2021).

Jika masyarakat desa mengalami hambatankurang terjangkaunya jaringan internet. Namun, berbeda dengan masyarakat kota sepeti Kota Mojokerto, hampir semua anak-anak memiliki sarana dan prasarana yang memadai. Mulai dari memiliki telepon pintar (smartphone) sampai hampir setiap rumah dan fasilitas umum memiliki jaringan internet yakni biasa disebut dengan WiFi (Wireless Fidelity). Hal tersebut membuat para pelajar mudah dalam mengakses apapun termasuk digunakan untuk pembelajaran jarak jauh selama pandemi. Tetapi, dampak negatif dalam hal ini yaitu anak sering lalai saat mengerjakan tugas sekolah daring. Dengan adanya saranan dan prasarana yang memadai membuat para pelajar melakukan kegiatan yang lain diluar tugas sekolah mereka. 
Ketika mereka sudah merasa bosan sekolah dari rumah, mereka memilih untuk bermain game online dan keluar rumah untuk bermain dengan teman sepermainan mereka. Selain itu, ketika orang tua yang sibuk bahkan ada yang tidak mau tau dalam pendampingan anak mereka dalam sekolah daring, sehingga membuat tugas anak-anak mereka terbengkalai.

Program pengabdian pada masyarakat ini sungguh bertujuan mengoptimalisasikan pembelajaran daring agar meningkatkan semangat dan motivasi anak - anak serta meringankan kesulitan yang di hadapi orang tua dan para siswa dalam belajar jarak jauh akibat covid - 19, program tersebut yaitu berupa pendampingan belajar daring dan pendampingan belajar di TPQ. Pelaksanaan pengabdian masyarakat dilakukan di Lingkungan Griya Permata Meri RT 05/RW 06 Kota Mojokerto yang telah dilakukan pada bulan Agustus 2021 dengan rincian 2 kali dalam sepekan. Tahap awal melakukan koordinasi dengan ijin pelaksanaan pengabdian masyarakat kepada RT Griya Permata Mer RT 05/RW 06 dan Ketua TPQ Nurul Qur'an.

Setelah hasil koordinasi dengan pihak mitra dampingan diterima kemudian melaksanakan program kerja yang akan dilakukan. Pelaksanaan kegiatan ini di berada di gazebo yang disediakan oleh RT setempat yang memiliki fasilitas umum wifi. Dengan adanya wifi gratis, para siswa sering menghabiskan waktunya hanya dengan bermain gadget atau game online maka dari itu pengabdian ini berupa dampingan, motivasi dan pembelajaran inovatif kepada anak - anak.

Pada program kegiatan pengabdian pendampingan belajar kepada siswa sekolah dasar Lingkungan Griya Permata Meri RT 05/RW 06 Kota Mojokerto, yaitu program kerja yang mencakup untuk mengoptimalisasikan pembelajaran daring. Dengan program kerja antara lain:

1. Sosialiasi dan Edukasi Pencegahan COVID - 19

Menurut Surat Edaran

(Kemenkes RI, 2020) Pedoman
Pencegahan dan Pengendalian Coronavirus Disease (COVID-19) yang dikeluarkan pada 16 Maret 2020, penanganan yang efektif di masyarakat dalam pencegahan penyebaran COVID - 19 yaitu:

a. Menjaga kebersihan tangan dengan melakukan mencuci tangan menggunakan sabun atau hand sanitizer.

b. Saat batuk dan bersin lakukan dengan menutup hidung menggunakan tisu atau lengan atas bagian dalam, lalu buang tisu tersebut ke tempat sampah

c. Memakai masker, pastikan masker sudah menutup mulut, hidung dan dagu.

d. Menghindari menyentuh hidung, mata, dan mulut sebelum melakukan cuci tangan.

e. Menjaga jarak dengan orang lain yang mengalami gejala COVID19 minimal 1 (satu) meter.

Sosialisasi dan Edukasi COVID-19 ini diberikan kepada pelajar siswa sekolah dasar mengenai informasi tentang pencegahan penularan virus COVID-19. Sebelum melakukan kegiatan pendampingan belajar, semua diwajibkan tetap menerapkan protokol kesehatan COVID-19. Sosialisasi dilaksanakan saat pertemuan pertama kami sebagai tim pendamping, agar para pelajar tetap mematuhi protokol kesehatan saat kegiatan berlangsung serta diterapkan terus selama melakukan kegiatan diluar rumah. Dalam fasilitas gazebo setempat sudah disediakan tempat cuci tangan dan sabun untuk mencuci tangan. Kesadaran para pelajar ini masih kurang dalam pentingnya menerapkan gerakan $3 \mathrm{M}$ di kalangan anakanak. Pengamatan terhadap aktivitas masyarakat terutama anak-anak di Lingkungan Perumahan Meri, menunjukkan para pelajar ini berkumpul bermain tanpa menggunakan masker. Tim pendamping dalam kegiatan ini memberikan edukasi tentang gejala dan langkah-langkah pengobatan jika terinfeksi COVID-19 serta cara mencegah penularan COVID-19 seperti 
mencuci tangan yang baik dan benar, pentingnya penggunaan masker, menjaga jarak serta mengurangi ativitas di luar rumah.

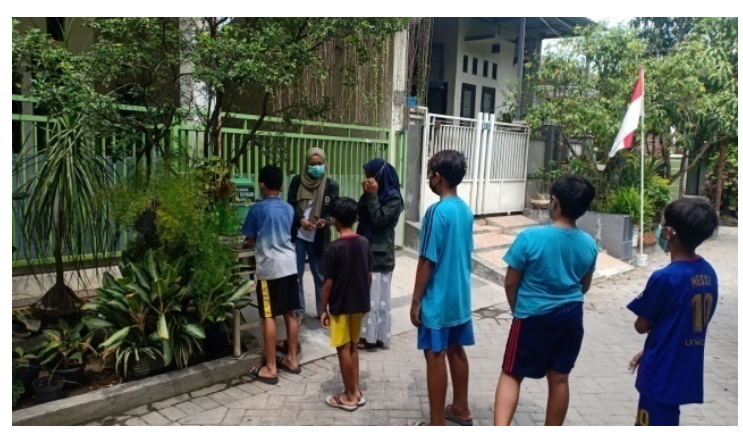

Gambar 1. Sosialisasi Pencegahan COVID-19

Ketika sosialisasi berlangsung anakanak sangat antusias dalam mempraktikan pencegahan protokol covid 19. Maksud dan tujuan dilaksanakan kegiatan ini adalah untuk meningkatkan kesadaran publik khususnya masyarakat griya permata meri RT 05/RW 06 dan bertujuan untuk saat pendampingan pembelajaran kedepan mereka tetap patuh dengan protokol kesehatan Covid-19. Kemudian untuk tujuan jangka panjang diharapkan kepada masyarakat dalam melakukan kegiatan apapun mereka juga tidak lupa akan pentingnya menjaga protokol kesehatan covid-19 selama pandemi.

2. Program Pendampingan Belajar secara Luring maupun Daring (Blended Learning)

Kedudukan peran orangtua dalam pendampingan belajar pada anak sangat penting karena orang tua harus membagi peran menjadi orang tua sekaligus guru bagi anak-anak mereka selama belajar dari rumah. Orang tua harus memberikan perhatian yang lebih pada anak-anak mereka saat pembelajaran daring. Hal ini dianggap sulit karena sebagian orang tua seakanakan sudah menyerahkan pendidikan anaknya pada lingkungan sekolah karena dengan alasan mereka sudah sibuk dengan pekerjaannya masingmasing (Ramdan \& Fauziah, 2019). Dalam kondisi apapun seorang orang tua adalah kunci keberhasilan bagi anak mereka. Oleh karena itu meskipun dalam kondisi pandemi, dan sekalipun sudah dalam kondisi normal peran orang tua tetaplah menjadi kunci utama akan tumbuh kembang anak. Penelitian terdahulu (Syahrul \& Nurhafizah, 2021) menuturkan, bahwa keterlibatan orang tua dalam pendampingan belajar anak selama pandemi yakni penting sebagai lingkungan pendidikan pertama dalam membimbing anak-anak mereka di mana terdapat pengaruh antara pola asuh terhadap perkembangan sosial emosional anak. Namun di Kota Mojokerto ini khususnya pada lingkungan Griya Permata Meri RT 05 RW 06, kebanyakan orang tua mereka sibuk dengan pekerjaannya masingmasing sehingga anak menjadi tidak terarah saat pembelajaran jarak jauh ini. Hal tersebut cukup disayangkan karena anak - anak butuh motivasi dari orang tua mereka disaat pembelajaran berlangsung.

Tim pendamping dalam kegiatan pembelajaran menggunakan metode pembelajaran blended learning yakni metode pembelajaran yang menggabungkan pembelajaran tatap muka dan jarak jauh (Kurniawati et al., 2019). Program kerja ini bertujuan untuk membantu kesulitan pada anak anak dalam pembelajaran daring, membantu meringankan beban orang tua dalam mengajarkan anak - anak mereka, memanfaatkan fasilitas umum menjadi lebih produktif yang di harapkan dapat membantu anak - anak dalam mengurangi ketergantungan dalam penggunaan gagdet. Dengan cara pendampingan blended learning, kegiatan bimbingan luring diharapkan agar pembelajaran kepada para siswa menjadi komunikasi lebih efektif, efisien, meningkatkan aksesbilitas dan pembelajaran menjadi tidak kaku karena terjadinya komunikasi dua arah (Nurin, 2017). Kegiatan pembelajaran seperti ini akan membuat para siswa 
tidak mudah bosan dan bermalas malasan dalam mengerjakan tugasnya dikarenakan mereka dapat bertemu dengan teman sebayanya dan langsung mendapat feedback dari pendamping belajarnya atas suatu pencapaian yang sudah dilakukan oleh mereka. Kemudian kegiatan daring melalui WhatsApp, para siswa diperbolehkan untuk bertanya mengenai materi yang kurang dipahami melalui grup yang sudah dibuat. Para pendamping akan membantu dengan semaksimal mungkin, pendamping membalas pesan dapat berbentuk pesan suara, gambar, maupun video.

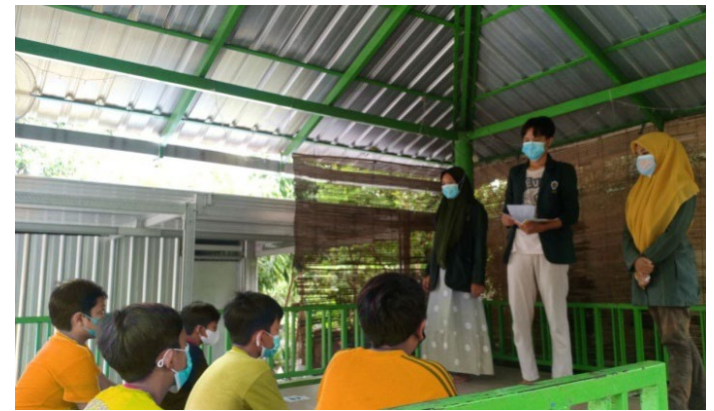

Gambar 2. Kegiatan Pendampingan

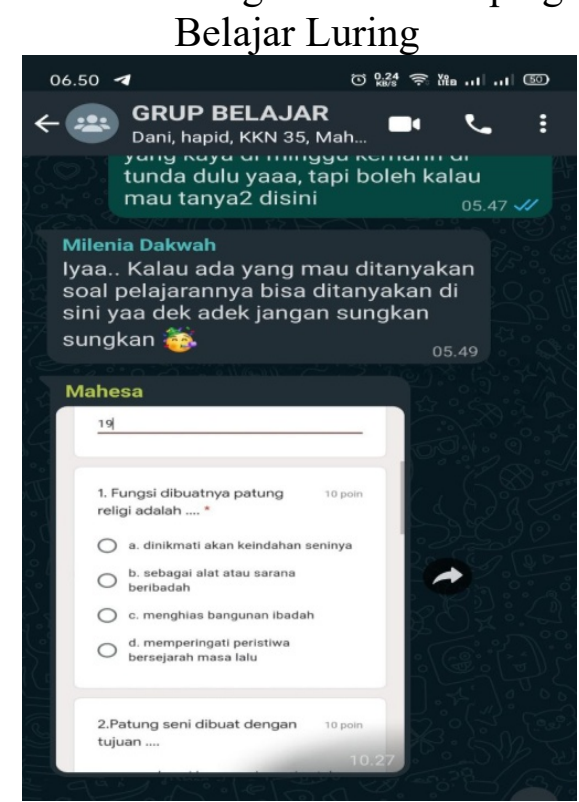

Gambar 3. Kegiatan Pendampingan Belajar Daring

Dalam pendampingan belajar ini kami tetap mematuhi protokol kesehatan 3M, mencuci tangan, memakai masker, dan menjaga jarak. Para siswa sangat antusias saat pendampingan berlangsung, mereka dapat memahami lebih mudah saat pembelajaran secara tatap muka dibandingkan belajar mandiri. Hal ini ditunjukkan saat mereka mengerjakan tugas dari sekolah dengan baik, yang sebelumnya tim pendamping menjelaskan materi sesuai tugas yang akan dikerjakan tersebut. Cukup disadari para pelajar sekolah dasar ini sangat butuh dampingan secara langsung dalam belajar, jika hanya melalui video saja belum tentu mereka dapat memahami dengan baik. Tim pendamping memberikan motivasi dan pembelajaran inovatif kepada para siswa saat pendampingan berlangsung, agar selalu semangat belajar dalam keadaan apapun.

3. Program Pendampingan TPQ

Pelaksanaan pendampingan dilakukan di TPQ yang tidak jauh dari lingkungan Griya Permata Meri RT 05/RW 06 yaitu TPQ Nurul Qur'an. Rincian mengajar di TPQ setiap hari Senin dan Rabu pada sore hari pukul $15.00-17.00$ WIB. Siswa yang ada di TPQ Nurul Qur'an terdiri dari 25 anak dari usia SD - SMP. Tim pendamping mendampingi anak - anak mengaji, muraja'ah dalam menjaga hafalan AlQur'an, menghafal surat - surat pendek, praktik sholat yang baik dan benar, menulis ayat Al - Qur'an serta menghafal doa sehari - hari. Program ini bertujuan Dalam era globalisasi saat ini peran TPQ sangat penting, karena untuk penangkal pengaruh dampak negatif di masyarakat akibat globalisasi.

Sekolah merupakan tempat yang menjadi tumpuan dalam memberi nilai - nilai pendidikan karakter religius, namun ternyata nilai - nilai tersebut belum dapat diterapkan secara optimal(Retnasari et al., 2019). Jika diamati pelajaran agama Islam kurang diperhatikan di sekolah umum karena mungkin sebatas pada pemenuhan isi kurikulum saja. Apalagi di masa pandemi seperti ini, anak - anak 
seringkali mengabaikan materi yang dibagikan oleh guru dan terkadang orang lain pula yang mengerjakan tugasnya. Oleh karena itu, Taman Pendidikan al-Qur'an juga merupakan tempat yang tepat untuk mendidik moral para pelajar dari sejak dini yang berasaskan al-Quran dan Hadist.

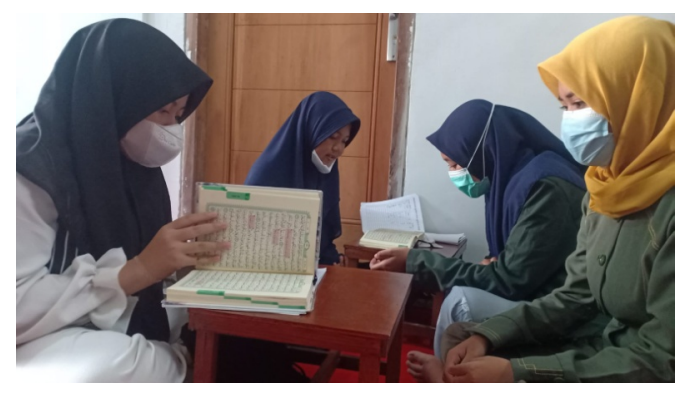

Gambar 4. Kegiatan Pendampingan

$$
\text { Belajar TPQ }
$$

Berdasarkan hasil di lapangan dapat disimpulkan, peran TPQ dapat memberikan tambahan wawasan pengetahuan dan keterampilan bagi anak-anak TPQ Nurul Quran agar lebih semangat dalam belajar Alquran. Tim pendamping menggunakan strategi pendampingan agar menciptakan suasana belajar menjadi lebih kondusif sehingga para santri dapat menerima dan memahami pembelajaran secara optimal. TPQ memiliki peran yang strategis dalam usaha penguatan pendidikan karakter religius pada anak. sehingga perlu adanya kerjasama yang terstruktur dengan baik antara lembaga pendidikan formal, TPQ dan keluarga.

4. Perlombaan Cerdas Cermat

Kegiatan perlombaan ini merupakan salah satu pembelajaran inovatif yang menyenangkan. Tujuan adanya program ini bertujuan agar anak - anak lebih semangat belajar dan dapat mereview ulang pembelajaran yang sebelumnya sudah di pelajari sehingga lebih dapat menguasai materi. Anak anak sangat antusias dalam berlomba menjawab pertanyaan yang disediakan, kegiatan ini juga dalam rangka memeriahkan Hari Ulang Tahun Indonesia yang ke-76 dengan tetap mematuhi protokol kesehatan. Tim pendamping juga sudah menyiapkan hadiah untuk peserta yang menang maupun tidak. Dengan adanya lomba cerdas cermat ini, diharapkan pada para pendamping anak - anak yakni wali murid untuk mengulang kembali materi yang sudah dipelajari, karena dapat meningkatkan daya ingat anak sehingga mereka dapat memahami materi dengan baik, serta dengan metode dengan diadakan perlombaan ini anak - anak menjadi tidak cepat bosan dalam belajar.

Dalam melakukan suatu pembelajaran memang perlu dilakukan suatu metode pembelajaran yang menarik dan menyenangkan sehingga para pelajar dapat lebih aktif dan berpartisipasi dalam proses belajar mengajar. Dengan diadakan lomba cerdas cermat ini, mengajak para pelajar dapat mengingat kembali materi apa yang telah didapatkan selama pendampingan 1 bulan ini. Para pendamping pun menjadi tahu permasalahan materi apa saja yang kurang dapat dipahami dengan baik oleh para siswa. Para pendamping pun dapat mengatasi masalah-masalah yang harus dipecahkan mengenai materi yang kurang dipahami oleh para siswa. Hasil menunjukkan para siswa sekolah dasar ini, sulit untuk memahami materi pelajaran sejarah dan matematika.

Jika diamati anak-anak saat ini dengan berkembangnya teknologi yang cukup pesat membuat anak-anak menjadi malas membaca buku dan lebih memilih bermain dengan telepon pintar yang mereka genggam di tangannya sendiri. Dengan minat baca anak yang rendah ini tentu menjadi sangat memprihatinkan. Padahal membaca dapat menambah wawasan ilmu pengetahuan. Jika sebelum pandemi muncul, perpustakaan di sekolah pun sudah jarang para siswa minat untuk berkunjung ke perpustakaan sekolah. Apalagi di masa pandemi saat ini, setiap 
harinya siswa hanya memegang telepon pintarnya saja. Untuk mengerjakan tugas pun mereka tinggal hanya mengetik soal yang sulit melalui internet. Kemudian langsung muncul jawaban dari soal itu. Para siswa pun tinggal menyalinnya saja tanpa mereka pahami tentang pertanyaan yang ditanyakan tersebut.

Dalam kegiatan pendampingan belajar ini merupakan mayoritas anakanak yang duduk dikelas kelas 5 dan 6 . Walaupun mereka sudah duduk di bangku kelas akhir, terdapat masih banyak siswa yang tidak dapat menghafal perkalian dengan baik. Menghafal memang bukan suatu hal yang mudah bagi beberapa orang, karena membutuhkan konsentrasi dan dan daya ingat yang tajam (Zulfitria, 2019). Pelajaran matematika juga sudah dianggap sebagai pelajaran yang menakutkan bagi kebanyakan siswa, salah satunya dengan materi perkalian.

Hasil di lapangan membuktikan hanya terdapat 1 siswa saja yang dapat menghitung hasil perkalian dengan cepat dan tepat. ketika tim pendamping menanyakan kepada mereka yang merasa kesulitan dalam pelajaran matematika, para siswa beralasan bahwa matematika itu sulit. namun dalam kenyataannya perkalian adalah pelajaran yang akan sering kita jumpai dalam kehidupan sehari-hari. Bagi siswa yang memiliki daya ingat yang tajam mungkin bukan menjadi masalah dalam menghafal perkalian sedangkan berbeda lagi dengan siswa yang memiliki kemampuan rata-rata tentunya akan merasa kesulitan. dengan hal ini tim pendamping mengajarkan pada mereka dengan metode yang mudah dalam menghafal perkalian yakni menghafal dengan lagu, mengapa dengan menggunakan trik 10 jari dan dengan kuis yang menyenangkan. dengan hal ini diharapkan para siswa dapat semangat belajar dengan tidak malas membaca dan tidak menganggap jika matematika itu sulit.

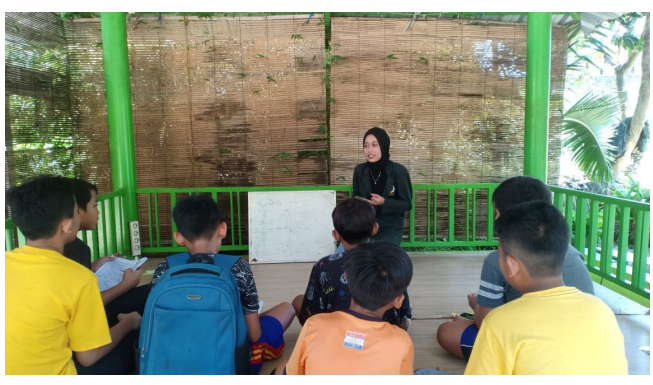

Gambar 5. Kegiatan Perlombaan Cerdas Cermat

Pendampingan kegiatan belajar di lingkungan Griya Permata Meri RT 05/RW 06 ini memiliki misi sederhana yakni untuk meningkatkan semangat dan motivasi anak sekolah dasar dalam pembelajaran jarak jauh di masa pandemi namun juga memiliki beberapa alasan lain. Pertama, melihat sarana dan prasarana yang memadai di lingkungan ini yakni gazebo yang telah disediakan RT setempet sehingga ditujukan untuk menggunakan fasilitas umum agar lebih produktif. Pada gazebo ini tersedia wifi gratis untuk masyarakat setempat. Oleh karena itu, dapat meningkatkan efisiensi dan efektifitas dalam pendampingan belajar daring.

Kedua, membantu meringankan beban orang tua dalam mengajarkan anak - anak mereka dirumah. Orang tua dari anak-anak tersebut kebanyakan adalah orang tua yang sibuk karena pekerjaan mereka. Sehingga anak-anak yang dalam dirinya tidak ada keinginan sendiri dalam mengerjakan tugas daring mengakibatkan lalai akan tugas sekolah yang diberikan oleh guru. Oleh karena itu, pendampingan pada siswa sekolah dasar ini sangat diperlukan sehingga dapat meningkatkan kesadaran tanggung jawab mereka sebagai seorang siswa. Ketiga, pendampingan belajar di TPQ Nurul Qur'an untuk meningkatkan spiritual pada anak sejak dini. Meskipun dalam keadaan pandemi seperti ini peran TPQ di lingkungan setempat sangat penting keberadaanya. 


\section{SIMPULAN}

Penelitian peneliti menghasilkan adanya pengoptimalan pendampingan belajar daring untuk mengurangi kecanduan gadget. Peneliti ingin menemukan data yang ada pada judul peneliti. Anak - anak SD di perumahan Griya Permata Meri awalnya jarang melakukan belajar pada saat pandemic, mereka malah bermain gadget dengan teman - temannya. Di perumahan tersebut terdapat fasilitas umum yakni gazebo dan juga wifi yang disediakan untuk melakukan belajar daring maupun orang orang yang sedang melakukan WFH (Work From Home). Akan tetapi anak - anak memanfaatkan fasilitas tersebut untuk bermain game online. Selama masa pandemic mereka belajarnya tidak menentu seperti yang dilakukan di sekolah. Anak anak lebih banyak bermain gadget daripada belajar. Anak - anak juga tidak memperhatikan protocol kesehatan yang dianjurkan oleh pemerintah setempat. Anak - anak bermain juga tidak memakai masker, setelah memegang hp juga terkadang langsung menyentuh makanan tanpa cuci tangan terlebih dahulu. Peneliti mengharapkan tulisan penelitian dapat bermanfaat bagi para orang tua, guru dengan mengoptimalkan pembelajaran daring di rumah.

Peneliti memiliki empat saran, yaitu: pendampingan belajar daring, melakukan kuis setelah belajar daring, mendalami kegiatan spiritual, mengajarkan prokes dengan baik. Pendampingan belajar daring ini dilakukan oleh orang tua yang memiliki anak sedang melakukan pembelajaran secara daring. Ketika anak - anak didampingi saat belajar daring, maka anak tersebut akan merasa diperhatikan dan ada yang mengajarkan tentang materi dari sekolah. Jadi ada yang mengawasi anak dengan benar supaya tidak menyalahgunakan hand phone untuk bermain game online, melakukan kuis setelah melakukan pendampingan adalah cara untuk mengetahui anak tersebut paham atau tidak dengan materi tersebut. Hal ini dilakukan supaya anak lebih memahami tentang pelajaran yang sudah dipelajari, karena kuis tersebut dilakukan seperti layaknya lomba cerdas cermat, jadi anak anak akan senang jika ada kuis setelah memahami pelajaran yang dipelajari. Mendalami kegiatan spiritual. Mendalami kegiatan spiritual dapat dilakukan dengan menyarankan anak untuk mengikuti TPQ yang berada di lingkungan sekitar. Mengikuti TPQ adalah cara untuk mendalami spiritual dengan mengaji al qur'an ataupun kajian - kajian keislaman. Mengikuti TPQ juga salah satu cara mengisi kegiatan anak selama di rumah saja. Hal ini dilakukan agar anak - anak tidak terus terusan bermain gadget. Selain mendapatkan ilmu tentang spiritual, mereka juga dapat mengisi waktu luang yang bermanfaat dan berdampak positif untuk kedepannya. Di TPQ juga banyak temannya yang bisa membuat anak - anak mengetahui tentang bersosialisasi agar tetap memiliki teman ketika di rumah saja. Mengajarkan protocol kesehatan dengan baik dan benar. Mengajarkan anak - anak mematuhi protocol kesehatan dimulai dari memakai masker ketika keluar rumah meskipun dekat. Lalu melakukan cuci tangan setelah keluar dari rumah, dan jika bepergian harus membawa handsanitizer sebagai pengganti cuci tangan jika ditempat tersebut tidak memungkinkan untuk cuci tangan. Lalu yang terakhir ialah menjaga jarak. Mematuhi protocol kesehatan diajarkan sejak dini agar terbiasa untuk mematuhi protocol kesehatan dimanapun mereka berada.

\section{DAFTARPUSTAKA}

Afandi, A. (2013). Articipatory Action

Research (Par) Metodologi Alternatif

Riset Dan Pengabdian Kepada

Masyarakat Transformatif.

PARTICIPATORY ACTION RESEARCH

(PAR) METODOLOGI ALTERNATIF

RISET DAN PENGABDIAN KEPADA

MASYARAKAT TRANSFORMATIF.

Fitrianto, A. R. (2021). Sustainable

Livelihood Approach Addressing 
Jurnal Edumaspul, 5 (2), Year 2021 - 73

(Alfath Iqbaal Chairulhaq, Alvina Mutia Hendarti, Reza Milenia Fendi, Achmad Room Fitrianto)

Community's Economic Distress

Facing the Covid 19 Outbreak: A

Methodological Concept. Proceedings

of the International Conference on

Business and Engineering

Management (ICONBEM 2021), 177,

55-61.

https://doi.org/10.2991/aebmr.k.210 522.009

Kemenkes RI. (2020).

SE_MENKES_202_2020_protokol_isol

asi_diri_COVID.pdf (pp. 1-4).

https://covid19.kemkes.go.id/downlo ad/SE_MENKES_202_2020_protokol_i solasi_diri_COVID.pdf

Kurniawati, M., Santanapurba, H., \& Kusumawati, E. (2019). Penerapan

Blended Learning Menggunakan Model Flipped Classroom Berbantuan Google Classroom Dalam

Pembelajaran Matematika Smp. EDUMAT: Jurnal Pendidikan Matematika, 7(1), 8-19.

https://doi.org/10.20527/edumat.v7i 1.6827

Nuriansyah, F., Ismanto, E., Novalia, M., \& Herlandy, P. B. (2020). Efektifitas

Penggunaan Media Online Dalam Meningkatkan Hasil Belajar Pada Mahasiswa Pendidikan Ekonomi Saat Awal Pandemi Covid-19. Jurnal Pengabdian UntukMu NegeRI, 1(1), 61-65.

https://ejournal.upi.edu/index.php/JP El/article/view/28346

Nurin, F. (2017). Penerapan Model Pembelajaran Blended Learning Pada Mata Kuliah Pemisahan Kimia Materi Kromatografi Untuk Meningkatkan Kualitas Belajar. Erudio Journal of Educational Innovation, 4(1), 46-54. https://doi.org/10.18551/erudio.4-1.5

Prawanti, L. T., \& Sumarni, W. (2020). Kendala Pembelajaran Daring Selama Pandemic Covid-19. Prosiding Seminar
Nasional Pascasarjana UNNES, 286291.

Rahmat, A., \& Mirnawati, M. (2020). Model Participation Action Research Dalam Pemberdayaan Masyarakat. Aksara: Jurnal Ilmu Pendidikan Nonformal, 6(1), 62. https://doi.org/10.37905/aksara.6.1.6 2-71.2020

Ramdan, A. Y., \& Fauziah, P. Y. (2019). Peran orang tua dan guru dalam mengembangkan nilai-nilai karakter anak usia sekolah dasar. Premiere Educandum : Jurnal Pendidikan Dasar Dan Pembelajaran, 9(2), 100. https://doi.org/10.25273/pe.v9i2.450 1

Retnasari, L., Suyitno, S., \& Hidayah, Y. (2019). Penguatan Peran Taman Pendidikan Al-Quran (TPQ) Sebagai Pendidikan Karakter Religius. Jurnal SOLMA, 8(1), 32. https://doi.org/10.29405/solma.v8i1. 2968

Rosiyanti, H., \& Muthmainnah, R. N. (2018). Penggunaan Gadget Sebagai Sumber Belajar Mempengaruhi Hasil Belajar Pada Mata Kuliah Matematika Dasar. FIBONACCI: Jurnal Pendidikan Matematika Dan Matematika, 4(1), 25. https://doi.org/10.24853/fbc.4.1.2536

Sumarno. (2020). Adaptasi Sekolah dalam Mengimplementasikan Pembelajaran Jarak Jauh Pada Masa Pandemi Covid19 (Studi Kasus SMP Muhammadiyah Karanggeneng Kabupaten Lamongan). Tarbiyah \& IImu Keguruan JTIK, 149162.

Suprihatin, A., Ananda, T. A., Mahsa, N., Damayanti, W., Alfiyah, G., Nurulita, M. F., \& Arifin, R. (2020). Efektivitas Pendampingan Belajar Anak Dalam Mengatasi Kesulitan Orang Tua Saat 
Jurnal Edumaspul, 5 (2), Year 2021 - 74

(Alfath Iqbaal Chairulhaq, Alvina Mutia Hendarti, Reza Milenia Fendi, Achmad Room Fitrianto)

Pembelajaran Daring Di Masa

Pandemi Di Desa Kebulusan,

Kabupaten Kebumen. 1-6.

Syah, R. H. (2020). Dampak Covid-19 pada

Pendidikan di Indonesia: Sekolah, Keterampilan, dan Proses

Pembelajaran. SALAM: Jurnal Sosial

Dan Budaya Syar-I, 7(5).

https://doi.org/10.15408/sjsbs.v7i5.1

5314

Syahrul, S., \& Nurhafizah, N. (2021).

Analisis Pengaruh Pola Asuh Orang

Tua Terhadap Perkembangan Sosial

dan Emosional Anak Usia Dini Dimasa

Pandemi Corona Virus 19. Jurnal

Basicedu, 5(2), 683-696.

https://doi.org/10.31004/basicedu.v5i

2.792

Syanas, K. L. N., Saputro, S., Indriyanti, N. Y., \& Mulyani, S. (2019). Metode

Pertanyaan Socrates dalam

Pembelajaran Materi Koloid

Menggunakan Participatory Action

Research (PAR). Jurnal Kimia Dan

Pendidikan Kimia (JKPK), 4(3), 232240.

World Health Organization. (2021). WHO

Coronavirus (COVID-19) Dashboard.

Covid19.Who.Int.

https://covid19.who.int/table

Yuhenita, N. N., Majid, Y. M., Murat, A. R., \& ... (2021). Pendampingan Dalam Menghadapi Pembelajaran Di Masa Pandemi Bagi Warga Dusun Macanan. Selaparang ..., 4(April), 215-219. http://journal.ummat.ac.id/index.php /jpmb/article/view/3711

Zulfitria. (2019). Upaya Meningkatkan Hafalan Perkalian Matematika dengan Menggunakan Metode Bernyanyi pada Siswa Kelas 2 SD di
Muhammadiyah 12 Pamulang Banten. Jurnal Instruksional, 1, 8.

\section{Profil Penulis}

Achmad Room Fitrianto kelahiran Sidoarjo, 27 Juni 1977, menyelesaikan Pendidikan Strata 1 di Universitas Airlangga pada 2002, menyelesaikan pendidikan S-2 Di IAIN Sunan Ampel pada 2006, menyelesaikan pendidikan Master of Arts in Public Policy, the School of Social Science and Humanities di Murdoch University, Perth. Australia pada 2019, dan mendapatkan gelar PhD Student in Anthropology, Environment and Resource Economics studies di Curtin University, Perth ,Australia pada 2012. Berkecimpung dalam dunia pendidikan dan berbagai penelitian yang berfokus pada pengabdian masyarakat.

Alfath Iqbaal Chairulhaq,lahir di Sidoarjo tanggal 18 Mei 2000 saat ini sedang menempuh Strata 1 di UIN Sunan Ampel Surabaya dan berada di semester 7. Seharihari memiliki aktifitas berkecimpung dalam dunia pendidikan sebagai mahasiswa yang aktif menanggapi isu-isu umum yang terjadi di masyarakat.

Alvina Mutia Hendarti, Lahir di Jombang, 05 Juni 2001, saat ini sedang menempuh Strata 1 dan berada di semester 7. Sehari-hari memiliki aktifitas berkecimpung di dalam pendidikan sebagai Mahasiswa UIN Sunan Apel Surabaya dan melakukan berbagai kegiatan keilmuan

Reza Milenia Fendi,lahir di Jombang tanggal 24 Februari 2000 saat ini sedang menempuh Strata 1 dan berada di semester 7. Sehari-hari memiliki aktifitas berkecimpung di dalam pendidikan sebagai Mahasiswa UIN Sunan Apel Surabaya dan organisasi kemahasiswaan . 